\title{
An Evaluation of the Use of Formic Acid for Extraction of Trace Elements from Brazil Nut and Babassu Coconut and Its Suitability for Multi-Element Determination by ICP-MS
}

\author{
Gisele S. Lopes, ${ }^{* a}$ Francisco L. F. Silva, ${ }^{a}$ Patricia Grinberg ${ }^{b}$ and Ralph E. Sturgeon ${ }^{b}$ \\ ${ }^{a}$ Laboratório de Estudos em Química Aplicada (LEQA), Departamento de Química Analítica e \\ Físico-Química, Universidade Federal do Ceará (UFC), 60455-760 Fortaleza-CE, Brazil \\ ${ }^{b}$ Chemical Metrology, Measurement Science and Standards, National Research Council of Canada, \\ Ottawa, Canada
}

\begin{abstract}
Formic acid extractions of Brazil nut and babassu coconut samples were undertaken prior to determination of $\mathrm{Al}$, As, $\mathrm{Ba}, \mathrm{Co}, \mathrm{Cr}, \mathrm{Cu}, \mathrm{Mn}, \mathrm{Mo}, \mathrm{Ni}, \mathrm{Pb}, \mathrm{Se}, \mathrm{Sr}, \mathrm{V}$ and $\mathrm{Zn}$ in their meat and oil portions by inductively coupled plasma mass spectrometry (ICP-MS) in an effort to accomplish a first order fractionation of the trace elements between these two components. An optimized full factorial design was applied to establish the best conditions for extraction. Microwave-assisted nitric acid digestions of samples and fractions along with analysis of certified reference material TORT-2 established the efficiency of recovery of the trace elements as well as provided a verification of accuracy. The multiple responses were analyzed using a desirability function wherein the recovery of the trace elements by extraction was compared with the determination of the total content as determined by nitric acid digestion. Although most trace elements presented a recovery higher than $85 \%$ using a formic acid extraction, $\mathrm{Al}$ suffered consistently low results for all samples (40-50\%). Except for $\mathrm{Al}$ and $\mathrm{Cr}$, the majority of the trace elements were present in the defatted fraction of both samples, i.e., $\mathrm{Al}$ (50 and 10\%), Cr (86 and 60\%), Ni (30 and 10\%) and $\mathrm{Sr}(8$ and 20\%) in Brazil nut and babassu coconut oil fractions, respectively.
\end{abstract}

Keywords: formic acid extraction, trace elements, nuts, fractionation, ICP-MS

\section{Introduction}

Most spectroanalytical techniques rely on the introduction of solutions, ${ }^{1}$ consequently, development of methods for digestion and solubilization of solid samples has been extensively pursued. The majority of published procedures rely on use of concentrated acids under conditions of elevated temperature and pressure to enhance the oxidation potential of the acids to ensure rapid and complete decomposition and solubilization, simultaneously converting analytes into simple inorganic species. Ultratrace analysis imposes stringent requirements on the purity and amount of reagents consumed as well as selection of procedures that minimize contamination arising from manipulation or loss of analytes by volatilization.

When considering quantitation by inductively coupled plasma mass spectrometry (ICP-MS), complex matrices frequently require additional post dissolution treatment

*e-mail: gslopes@ufc.br such as dilution of the digest to minimize dissolved solids content or mitigate severe spectral interferences or their evaporation to remove acids. ${ }^{1}$

Alternatives to acid digestion of samples have been explored, ${ }^{2}$ in particular, for botanical and biological matrices. One such approach is treatment of samples with formic acid. ${ }^{3-6}$ Formic acid has also been explored as a reagent to promote photochemical vapor generation $(\mathrm{PVG}){ }^{7-11}$ thereby permitting more efficient introduction of gaseous analytes into spectrochemical sources to improve detection limits.

Brazil nuts (Bertholletia excelsa) and babassu coconut (Orbignya phalerata) belong to the family of oil and edible seeds. They are high-energy almonds native to the Amazon region where they are consumed as food products (oil and meat) or used in the manufacture of cosmetics such as soaps (from babassu oil). ${ }^{12-14}$ In addition, Brazil nuts are recognized and marketed worldwide as enriched sources of selenium, an antioxidant implicated in the prevention of cancer and other diseases. ${ }^{15}$ 
Several studies describing the fractionation of Brazil nut to separate the defatted flour from the oil fraction can be found in the literature..$^{12,14,15}$ The principal interest of such investigations was identification of the specific proteins found in the defatted fraction that contained elements of interest, particularly Se compounds.

Within the context of the above, the objective of this work was to explore the use of formic acid for the efficient solubilization of Brazil nut samples and babassu coconut for the determination of $\mathrm{Al}, \mathrm{As}, \mathrm{Ba}, \mathrm{Co}, \mathrm{Cr}, \mathrm{Cu}, \mathrm{Mn}, \mathrm{Mo}, \mathrm{Ni}$, $\mathrm{Pb}, \mathrm{Se}, \mathrm{Sr}, \mathrm{V}$ and $\mathrm{Zn}$ content by ICP-MS as well as employ a first order fractionation scheme to evaluate the partitioning of select elements between their oil and meat phases.

\section{Experimental}

\section{Apparatus}

All measurements were performed using an ELAN DRC II ICP-MS (PerkinElmer Sciex, Shelton, CT, USA) operating in standard mode (the dynamic reaction cell (DRC) system was functioning unreliably during the period of this study), equipped with a cyclonic glass spray chamber and a Meinhard concentric nebulizer. The ICP-MS was operated in accordance with the manufacturer's recommended conditions. Instrumental parameters comprised the following: RF power: $1100 \mathrm{~W}$; plasma gas flow rate: $15 \mathrm{~L} \mathrm{~min}^{-1}$; auxiliary gas flow rate: 1.20 L min'-1; nebulizer gas flow rate: $0.96 \mathrm{~L} \mathrm{~min}^{-1}$ and a sample introduction flow rate of $1.4 \mathrm{~mL} \mathrm{~min}^{-1}$.

Wet digestions were conducted using a Multiwave 3000 closed-vessel microwave digestion system (Anton Paar, Graz, Austria) equipped with 16 fluoropolymer vessels and ceramic vessel jackets. A DigiPrep digestion block (SCP Science, Quebec, Canada) was used to evaporate sample-digests.

Shelled raw nut samples were cold pressed using a MA 098/50A/1 hydraulic press (Marconi, Piracicaba, SP, Brazil) to remove the oil fraction. The resulting solid cake was subsequently subjected to a Soxhlet extraction with hexane to ensure complete removal of the lipid fraction.

The defatted samples were freeze-dried over a period of several days in an L 108 freeze-drier (Liobras, São Carlos, SP, Brazil).

\section{Reagents and solutions}

Sub-boiling distilled nitric acid was prepared from reagent grade feedstock under class 100 clean room conditions. Concentrated formic acid $\left(88 \% \mathrm{~m} \mathrm{~m}^{-1}\right)$ was obtained from Anachemia (Montreal, QC, Canada). High purity de-ionized water (DIW) was produced by reverse osmosis followed by a deionization (Barnsted/Thermolyne, Dubuque, IA, USA) to yield $18 \mathrm{M} \Omega \mathrm{cm}$ resistivity reagent.

Calibration solutions of $\mathrm{Al}, \mathrm{As}, \mathrm{Ba}, \mathrm{Co}, \mathrm{Cr}, \mathrm{Cu}, \mathrm{Mn}$, $\mathrm{Mo}, \mathrm{Ni}, \mathrm{Pb}, \mathrm{Se}, \mathrm{Sr}, \mathrm{V}$ and $\mathrm{Zn}$ were prepared by serial dilution of high purity $1000 \mathrm{mg} \mathrm{kg}^{-1}$ commercial standards (SCP Science, Montreal, Canada) with DIW containing $1 \% \mathrm{HNO}_{3}$.

Hexane was purchased in high purity from SigmaAldrich (São Paulo, SP, Brazil).

Certified reference material (CRM) TORT-2 lobster hepatopancreas (NRC, Ottawa, Canada) was used for method validation.

\section{Procedures}

Shelled Brazil nut and babassu coconut samples were purchased from a local market in the city of Fortaleza, Ceará State, in the northeast region of Brazil. Samples were washed with DIW and dried at room temperature. Both matrices were rendered into a fine paste using a coffee grinder as a processing mill. The mill was precleaned by grinding a sacrificial subsample of each nut and discarding it before processing the final material used for analysis.

A portion of each of the ground samples was freeze-dried and stored under vacuum. A separate portion of $20 \mathrm{~g}$ of each sample was placed between pre-cleaned and dried pieces of thin, muslin fabric and cold pressed at $150 \mathrm{~kg} \mathrm{~cm}^{-2}$ for $15 \mathrm{~s}$ to extract the oil. The oil was subsequently filtered by passing it through a pre-cleaned Whatman grade 1 filter paper $(11 \mu \mathrm{m})$ and then stored in $15 \mathrm{~mL}$ amber glass vials at ambient temperature. The solid residue (cake) was further treated to ensure removal of any residual oil by subjecting it to a Soxhlet extraction using hexane as solvent. The total oil fraction was determined by summing the weight of the initial pressed fraction with that recovered from the Soxhlet procedure (following evaporation of the hexane). The defatted fraction of the sample was freeze-dried and vacuum packed.

The formic acid solubilization procedure was optimized using a full factorial with center point experimental design. For this purpose, $250 \mathrm{mg}$ sub-samples of CRM TORT-2 were weighed directly into polypropylene tubes and $8 \mathrm{~mL}$ $\mathrm{HCOOH}$ were added. The mixtures were placed in a thermostated $\left(50^{\circ} \mathrm{C}\right)$ ultrasound bath (frequency of $20 \mathrm{kHz}$, $80 \mathrm{~W}$ power) for periods of $1-3 \mathrm{~h}$ and then transferred to a $60{ }^{\circ} \mathrm{C}$ heating bath for varying times up to $15 \mathrm{~h}$. Samples were then diluted to $30 \mathrm{~mL}$ with DIW to provide a medium containing 3.5\% $\left(\mathrm{v} \mathrm{v}^{-1}\right) \mathrm{HCOOH}$. All experiments were carried out in triplicate. 
Microwave-assisted nitric acid digestion of CRM TORT-2 as well as the samples was performed. Sub-samples ranging from $150-250 \mathrm{mg}$ were accurately weighed and transferred to the fluoropolymer digestion vials, $6.0 \mathrm{~mL}$ $\mathrm{HNO}_{3}$ were added and the vials were sealed. The microwave heating program comprised the following steps: (i) a linear ramp of applied power to $1300 \mathrm{~W}$ over $10 \mathrm{~min}$; (ii) a hold for $25 \mathrm{~min}$ at $1300 \mathrm{~W}$; and (iii) cooling utilizing maximum air flow in the microwave cavity until the vessels reached room temperature. After digestion, solutions were transferred to polypropylene vials, evaporated to about $1 \mathrm{~mL}\left(90^{\circ} \mathrm{C}\right)$ using the digestion block and then diluted to $30 \mathrm{~mL}$ with $0.5 \%\left(\mathrm{v} \mathrm{v}^{-1}\right) \mathrm{HNO}_{3}$.

A four-point method of additions was used for the determination of all analytes in both microwave-assisted digested as well as formic acid extracted solutions to obviate any potential matrix interferences. The following isotopes were selected for measurement: ${ }^{27} \mathrm{Al},{ }^{75} \mathrm{As},{ }^{138} \mathrm{Ba}$, ${ }^{59} \mathrm{Co},{ }^{53} \mathrm{Cr},{ }^{63} \mathrm{Cu},{ }^{55} \mathrm{Mn},{ }^{98} \mathrm{Mo},{ }^{58} \mathrm{Ni},{ }^{208} \mathrm{~Pb},{ }^{82} \mathrm{Se},{ }^{88} \mathrm{Sr},{ }^{51} \mathrm{~V}$ and ${ }^{64} \mathrm{Zn}$.

\section{Results and Discussion}

A survey of the literature on trace elements in Brazil nuts ${ }^{12-16}$ reveals a significant interest in selenium in this sample (likely due to its purported health benefits). CRM TORT-2 was selected for method development in this study because of an expected close match in selenium concentration to that of the real samples.

Table 1 summarizes results for analysis of the CRM TORT-2 validation sample following microwave-assisted nitric acid digestion. It is evident from a $t$-test that all results are in good agreement with the certified values at the $95 \%$ confidence level. Potential matrix interferences were compensated for using the method of additions for calibration. The formation of ${ }^{12} \mathrm{C}^{40} \mathrm{Ar}^{+}$precluded use of ${ }^{52} \mathrm{Cr}$ for quantitation while ${ }^{82} \mathrm{Se}$ was selected to avoid interferences from ${ }^{80} \mathrm{Ar}_{2}{ }^{+}$and ${ }^{40} \mathrm{Ar}^{38} \mathrm{Ar}^{+}$.

As the DRC was not functioning reliably during the course of this study, this precluded the ability to quantitate both trace $\mathrm{Fe}$ and $\mathrm{Cr}$ in the samples since the common isobaric interferences arising from $\mathrm{ArO}^{+}$and $\mathrm{ArC}^{+}$could no longer be eliminated when the formic acid medium was analyzed. Note that when the samples were digested using a microwave-assisted acid dissolution, the background from $\mathrm{ArC}^{+}$was sufficiently low to allow for determination of $\mathrm{Cr}$ in such solutions.

Attempts to solubilize CRM TORT-2 using formic acid were optimized using a full factorial with center point experimental design. The earlier published procedure ${ }^{3}$ was modified by the addition of a heating step using
Table 1. Results for CRM TORT-2

\begin{tabular}{lccc}
\hline Element & $\begin{array}{c}\text { Certified value / } \\
\left(\mathrm{mg} \mathrm{kg}^{-1}\right)\end{array}$ & $\begin{array}{c}\text { MW digestion / } \\
\left(\mathrm{mg} \mathrm{kg}^{-1}\right)\end{array}$ & Recovery / \% \\
\hline $\mathrm{Al}$ & $\mathrm{NA}$ & $23.5 \pm 3.7^{\mathrm{a}}$ & - \\
$\mathrm{As}$ & $21.6 \pm 1.8$ & $21.0 \pm 1.9$ & 97 \\
$\mathrm{Ba}$ & $\mathrm{NA}$ & $1.60 \pm 0.19$ & - \\
$\mathrm{Co}$ & $0.51 \pm 0.09$ & $0.51 \pm 0.07$ & 100 \\
$\mathrm{Cr}$ & $0.77 \pm 0.15$ & $0.75 \pm 0.17$ & 97 \\
$\mathrm{Cu}$ & $106 \pm 10$ & $98.5 \pm 20.3$ & 93 \\
$\mathrm{Mn}$ & $13.6 \pm 1.2$ & $12.5 \pm 2.7$ & 92 \\
$\mathrm{Mo}$ & $0.95 \pm 0.10$ & $0.98 \pm 0.09$ & 103 \\
$\mathrm{Ni}$ & $2.50 \pm 0.19$ & $2.48 \pm 0.14$ & 99 \\
$\mathrm{~Pb}$ & $0.35 \pm 0.13$ & $0.36 \pm 0.04$ & 102 \\
$\mathrm{Se}$ & $5.63 \pm 0.67$ & $5.50 \pm 0.71$ & 98 \\
$\mathrm{Sr}$ & $45.2 \pm 1.9$ & $45.0 \pm 1.4$ & 100 \\
$\mathrm{~V}$ & $1.64 \pm 0.19$ & $1.72 \pm 0.24$ & 104 \\
$\mathrm{Zn}$ & $180 \pm 6$ & $176 \pm 19$ & 98 \\
\hline
\end{tabular}

${ }^{\mathrm{a}}$ Confidence interval ( $t$ value: $\left.4.3,95 \%\right)$. MW: microwave; NA: not available.

a thermostated bath, otherwise recovery of As and Se was below $80 \%$. Although quantitative recovery of these elements was earlier reported when the digests were analyzed by graphite furnace atomic absorption spectrometry (GF AAS), ${ }^{3}$ it was evident that complete solubilization of the matrix is not achieved without the additional heating step. Since the digests were filtered prior to analysis in this study, whereas they were directly sampled for determination by GFAAS by Scriver et al., ${ }^{3}$ a significant fraction is lost from the filtrate that would otherwise have been pyrolyzed and contributed to response by GF AAS.

Selenium, mainly present as selenocysteine and selenomethionine amino acids in tissue samples ${ }^{16}$ may be difficult to recover with use of formic acid unless elevated temperatures are used ${ }^{17,18}$ and thus recovery of Se is not satisfactory if undigested proteins are removed by filtration prior to analysis of unheated mixtures. The presence of a residue requiring filtration leads to the conclusion that even with the addition of the heating step, extraction, rather than solubilization, is achieved.

The desirability function is a popular and established methodology for system optimization based on multiple input responses; the approach modified by Deringer and Suich ${ }^{19}$ described the relationship between response and dependent variables utilizing a desirability function which identifies the optimal (compromise) conditions. The response $Y$ in a desired individual function $d$ can range from 0 (representing a completely undesirable value) to 1 (representing an ideal response value). Figure 1 presents 
such a desirability function for the formic acid extraction approach based on multiple responses reflecting the recovery of trace elements from CRM TORT- 2 and the impact of both the "bath time" at $60{ }^{\circ} \mathrm{C}$ and the time the samples were subjected to the ultrasonication at $50^{\circ} \mathrm{C}$, i.e., the "US time". It is evident that there is a large increase in the desirability (0.6) when subjecting the samples to $3 \mathrm{~h}$ of sonication combined with $7 \mathrm{~h}$ of heating.

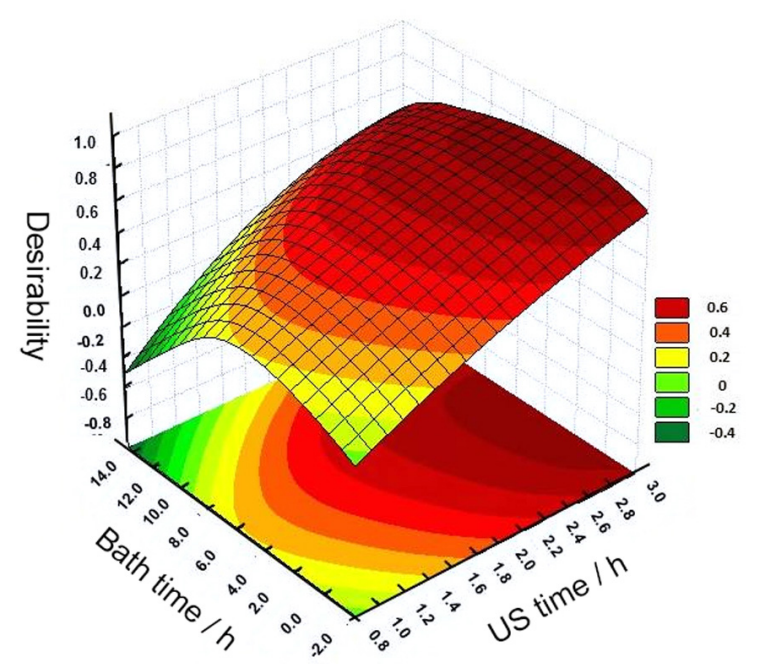

Figure 1. Desirability function response surface for "bath time" $v s$. US time.

Experimentally, the impact of the $60{ }^{\circ} \mathrm{C}$ heating step had a positive influence on recovery of $\mathrm{As}, \mathrm{Cu}$, Se and $\mathrm{Zn}$, increasing it from 75 to $95 \%$. Greater than $95 \%$ recoveries were obtained for $\mathrm{Ba}, \mathrm{Co}$ and Mo when the sample was exposed to the ultrasonic bath for $3 \mathrm{~h}$ at $50{ }^{\circ} \mathrm{C}$. On the other hand, recovery of $\mathrm{Mn}, \mathrm{Ni}, \mathrm{Pb}$ and $\mathrm{V}$ was readily achieved by following the simplified digestion procedure. ${ }^{3}$

The optimized (compromised) response for all elements was obtained using the following formic acid extraction procedure: $0.25 \mathrm{~g}$ sub-samples mixed with $8 \mathrm{~mL} \mathrm{HCOOH}$ $(88 \%)$ and subjected to a $3 \mathrm{~h}$ ultrasonic bath at $50{ }^{\circ} \mathrm{C}$ followed by $7 \mathrm{~h}$ at $60^{\circ} \mathrm{C}$ in a thermostated bath.

Table 2 summarizes estimated limits of quantification (LOQ) calculated as 10-fold the standard deviation of 10 replicate measurements of the blank divided by the slope of the analytical calibration curve and multiplied by the sample dilution factor. The LOQs for $\mathrm{Al}, \mathrm{As}$ and $\mathrm{Ba}$ improved from 6- to 8-fold with formic acid extraction; $\mathrm{Mn}$ and $\mathrm{Ni}$ improved 5-fold and even Se presented a 3-fold better LOQ using this approach compared to analysis following microwave-assisted digestion with nitric acid.

Measurement sensitivity increased for all elements in the formic acid medium. This may arise because of an increase in ionization efficiency for a number of elements, possibly due to charge transfer by an elevated level of
Table 2. Estimated limits of quantification

\begin{tabular}{lcc}
\hline Element & $\begin{array}{c}\text { MW digestion / } \\
\left(\mu \mathrm{g} \mathrm{kg}^{-1}\right)\end{array}$ & $\begin{array}{c}\mathrm{HCOOH} \text { extraction / } \\
\left(\mu \mathrm{g} \mathrm{kg}^{-1}\right)\end{array}$ \\
\hline $\mathrm{Al}$ & 160 & 19 \\
$\mathrm{As}$ & 6.2 & 1.0 \\
$\mathrm{Ba}$ & 32 & 4.7 \\
$\mathrm{Co}$ & 2.6 & 1.7 \\
$\mathrm{Cr}$ & 40 & 260 \\
$\mathrm{Cu}$ & 64 & 20 \\
$\mathrm{Mn}$ & 29 & 6.0 \\
$\mathrm{Mo}$ & 12 & 11 \\
$\mathrm{Ni}$ & 38 & 9.2 \\
$\mathrm{~Pb}$ & 5.2 & 1.8 \\
$\mathrm{Se}$ & 76 & 23 \\
$\mathrm{Sr}$ & 1.5 & 1.6 \\
$\mathrm{~V}$ & 7.6 & 7.2 \\
$\mathrm{Zn}$ & 110 & 44 \\
\hline
\end{tabular}

MW: microwave.

$\mathrm{C}^{+}$species in the plasma, ${ }^{20}$ and also as a consequence of differing aerosol properties (i.e., surface tension and density) that increase the nebulization efficiency compared to solutions containing nitric acid. ${ }^{1,21}$ LOQs are improved in the formic acid medium due to enhanced sensitivity, lower blank values and improved measurement precision.

\section{Brazil nut samples}

Whole and defatted Brazil nut samples were processed with $\mathrm{HCOOH}$ using the optimized procedure identified by the experimental design. Results obtained for the determination of the trace elements by ICP-MS are summarized in Tables 3 and 4. Similarly to analysis of wet and dry fractions of materials, removal of the oil ( $64 \%$ by mass) has increased the relative concentration of all elements present in the defatted fraction.

The presence of carbon in the plasma may affect response as a consequence of both spectral and matrix interferences..$^{20} \mathrm{No}$ results are presented for $\mathrm{Cr}$ in a formic acid medium as significant interference on even ${ }^{53} \mathrm{Cr}$ remains due to the presence of large concentrations of carbon arising from both the formic acid and constituents of the sample matrix. ${ }^{22}$ As such, determination of $\mathrm{Cr}$ was only possible for samples subjected to the more complete oxidation achieved with microwave-assisted acid decomposition.

Reports of concentrations of Se and $\mathrm{Ba}$ in Brazil nuts reveal substantial variability; ${ }^{12-15,23}$ there is consensus that levels of Se in the nut kernels may vary with geographic location and soil characteristics in which they have been 
Table 3. Results for whole Brazil nuts extracted with formic acid and by microwave-assisted nitric acid digestion $(\mathrm{n}=3)$

\begin{tabular}{lccc}
\hline Element & MW digestion $/\left(\mathrm{mg} \mathrm{kg}^{-1}\right)$ & $\mathrm{HCOOH}$ extraction $/\left(\mathrm{mg} \mathrm{kg}^{-1}\right)$ & Recovery / \% \\
\hline $\mathrm{Al}$ & $2.61 \pm 0.06$ & $1.18 \pm 0.02$ & 45 \\
$\mathrm{As}$ & $0.058 \pm 0.003$ & $0.055 \pm 0.003$ & 95 \\
$\mathrm{Ba}$ & $849 \pm 35$ & $867 \pm 42$ & 102 \\
$\mathrm{Co}$ & $0.95 \pm 0.03$ & $0.94 \pm 0.06$ & 99 \\
$\mathrm{Cr}$ & $0.22 \pm 0.01$ & $\mathrm{ND}$ & - \\
$\mathrm{Cu}$ & $17.4 \pm 0.8$ & $18.1 \pm 0.9$ & 104 \\
$\mathrm{Mn}$ & $14.8 \pm 0.6$ & $15.1 \pm 0.4$ & 102 \\
$\mathrm{Mo}$ & $0.012 \pm 0.005$ & $0.010 \pm 0.006$ & 85 \\
$\mathrm{Ni}$ & $2.03 \pm 0.11$ & $1.82 \pm 0.06$ & 89 \\
$\mathrm{~Pb}$ & $0.009 \pm 0.001$ & $0.008 \pm 0.002$ & 88 \\
$\mathrm{Se}$ & $3.87 \pm 0.13$ & $3.76 \pm 0.25$ & 97 \\
$\mathrm{Sr}$ & $166 \pm 12$ & $158 \pm 10$ & 95 \\
$\mathrm{~V}$ & $0.018 \pm 0.001$ & $0.016 \pm 0.002$ & 89 \\
$\mathrm{Zn}$ & $45.0 \pm 1.5$ & $44.8 \pm 0.9$ & 100
\end{tabular}

MW: microwave; ND: no interference-free isotope available for quantitation.

Table 4. Results for defatted Brazil nuts extracted with formic acid and by microwave-assisted nitric acid digestion $(\mathrm{n}=3)$

\begin{tabular}{lccc}
\hline Element & $\begin{array}{c}\text { MW digestion / } \\
\left(\mathrm{mg} \mathrm{kg}^{-1}\right)\end{array}$ & $\begin{array}{c}\mathrm{HCOOH} \\
\text { extraction / } \\
\left(\mathrm{mg} \mathrm{kg}^{-1}\right)\end{array}$ & Recovery / \% \\
\hline $\mathrm{Al}$ & $3.80 \pm 0.15$ & $1.97 \pm 0.15$ & 51 \\
$\mathrm{As}$ & $0.16 \pm 0.01$ & $0.14 \pm 0.02$ & 88 \\
$\mathrm{Ba}$ & $2200 \pm 130$ & $2112 \pm 98$ & 96 \\
$\mathrm{Co}$ & $2.60 \pm 0.12$ & $2.54 \pm 0.15$ & 98 \\
$\mathrm{Cr}$ & $0.12 \pm 0.01$ & $\mathrm{ND}$ & - \\
$\mathrm{Cu}$ & $47.2 \pm 2.1$ & $48.1 \pm 2.2$ & 102 \\
$\mathrm{Mn}$ & $40.3 \pm 2.0$ & $39.8 \pm 1.9$ & 99 \\
$\mathrm{Mo}$ & $0.034 \pm 0.001$ & $0.035 \pm 0.001$ & 103 \\
$\mathrm{Ni}$ & $4.22 \pm 0.13$ & $4.17 \pm 0.10$ & 99 \\
$\mathrm{~Pb}$ & $0.024 \pm 0.001$ & $0.022 \pm 0.002$ & 92 \\
$\mathrm{Se}$ & $10.5 \pm 0.5$ & $10.9 \pm 0.4$ & 104 \\
$\mathrm{Sr}$ & $426 \pm 13$ & $418 \pm 8$ & 98 \\
$\mathrm{~V}$ & $0.050 \pm 0.003$ & $0.048 \pm 0.001$ & 96 \\
$\mathrm{Zn}$ & $120 \pm 6$ & $123 \pm 5$ & 101 \\
\hline
\end{tabular}

MW: microwave; ND: no interference-free isotope available for quantitation.

grown. Naozuka et al..$^{13}$ reported concentrations of $\mathrm{Ba}$ of $470 \mathrm{mg} \mathrm{kg}^{-1}$ in Brazil nuts collected in Pará State (north region of Brazil). Selenium content was not measured, probably due to an insufficient LOQ available with the inductively coupled plasma optical emission spectrometry (ICP-OES) detection method used. Parekh et al..$^{24}$ attributed the high concentration of $\mathrm{Ba}$ found in Brazil nuts grown in the Amazon Basin of South America as due to the presence of a Ba-rich mineral (hollandite, $\mathrm{Ba}_{2} \mathrm{Mn}_{8} \mathrm{O}_{16}$ ) present in the soils. These authors encountered a range of 0.17 to $2000 \mathrm{mg} \mathrm{kg}^{-1}$ in samples collected in Northern South America, Brazil, Bolivia and Peru. In the present work, concentrations of $\mathrm{Ba}$ averaging $850 \mathrm{mg} \mathrm{kg}^{-1}$ were obtained in the whole Brazil nuts.

In the same manner, the concentrations summarized in Table 3 for other micronutrients in the Brazil nuts studied here, such as $\mathrm{Mn}$ and $\mathrm{Zn}$, are comparable to those reported by Naozuka et al., ${ }^{13}$ i.e., $\mathrm{Mn}\left(8.8 \mathrm{mg} \mathrm{kg}^{-1}\right)$ and $\mathrm{Zn}\left(39 \mathrm{mg} \mathrm{kg}^{-1}\right)$, and also by Santos et al., ${ }^{14}$ i.e., Mn (16.5 $\left.\mathrm{mg} \mathrm{kg}^{-1}\right)$ and $\mathrm{Zn}\left(35.1 \mathrm{mg} \mathrm{kg}^{-1}\right)$.

Results for the analysis of solutions prepared by microwave-assisted nitric acid digestion of these samples were compared to those obtained by formic acid extraction so as to calculate recoveries using the latter procedure. Recoveries of trace elements from the whole Brazil nut samples are summarized in Table 3 and ranged from 85 to $104 \%$ while those from the defatted samples, shown in Table 4, vary from 88 to $104 \%$. However, low recoveries are evident for $\mathrm{Al}$ in both the whole and defatted samples of the nut. This aspect needs further study.

\section{Babassu coconut samples}

Freeze-dried whole and defatted fractions of babassu coconut samples were also extracted with $\mathrm{HCOOH}$ using the earlier established optimized procedure. Results obtained for the determination of the trace elements are summarized in Tables 5 and 6 . As the microwave-assisted acid digestion methodology was previously validated 
(Table 1), such results were used as reference values for calculation of recoveries of elements subjected to the formic acid extraction procedure.

It is important to emphasize that the concentration levels of the elements found in such almonds can be different and are dependent on the plant physiology as well as characteristics of the soil in which they are grown. Each

Table 5. Results for whole babassu coconut extracted with formic acid and microwave-assisted nitric acid digestion $(\mathrm{n}=3)$

\begin{tabular}{lccc}
\hline Element & $\begin{array}{c}\text { MW digestion / } \\
\left(\mathrm{mg} \mathrm{kg}^{-1}\right)\end{array}$ & $\begin{array}{c}\mathrm{HCOOH} \\
\text { extraction / } \\
\left(\mathrm{mg} \mathrm{kg}^{-1}\right)\end{array}$ & Recovery / \% \\
\hline $\mathrm{Al}$ & $12.4 \pm 0.04$ & $5.21 \pm 0.22$ & 42 \\
$\mathrm{As}$ & $0.005 \pm 0.001$ & $0.004 \pm 0.001$ & 80 \\
$\mathrm{Ba}$ & $0.20 \pm 0.01$ & $0.17 \pm 0.01$ & 85 \\
$\mathrm{Co}$ & $0.034 \pm 0.002$ & $0.030 \pm 0.002$ & 88 \\
$\mathrm{Cr}$ & $0.18 \pm 0.01$ & $\mathrm{ND}$ & - \\
$\mathrm{Cu}$ & $14.1 \pm 0.6$ & $13.8 \pm 0.3$ & 98 \\
$\mathrm{Mn}$ & $32.2 \pm 1.2$ & $30.6 \pm 1.4$ & 95 \\
$\mathrm{Mo}$ & $0.27 \pm 0.01$ & $0.23 \pm 0.02$ & 85 \\
$\mathrm{Ni}$ & $0.33 \pm 0.01$ & $0.26 \pm 0.02$ & 80 \\
$\mathrm{~Pb}$ & $0.017 \pm 0.001$ & $0.016 \pm 0.002$ & 94 \\
$\mathrm{Se}$ & $0.54 \pm 0.02$ & $0.53 \pm 0.01$ & 98 \\
$\mathrm{Sr}$ & $1.13 \pm 0.05$ & $0.98 \pm 0.07$ & 86 \\
$\mathrm{~V}$ & $0.044 \pm 0.001$ & $0.046 \pm 0.002$ & 104 \\
$\mathrm{Zn}$ & $20.1 \pm 1.1$ & $20.8 \pm 0.9$ & 103 \\
\hline
\end{tabular}

MW: microwave; ND: no interference-free isotope available for quantitation.

Table 6. Results for defatted babassu coconut extracted with formic acid and microwave-assisted nitric acid digestion $(\mathrm{n}=3)$

\begin{tabular}{lccc}
\hline Element & $\begin{array}{c}\text { MW digestion / } \\
\left(\mathrm{mg} \mathrm{kg}^{-1}\right)\end{array}$ & $\begin{array}{c}\mathrm{HCOOH} \\
\text { extraction / } \\
\left(\mathrm{mg} \mathrm{kg}^{-1}\right)\end{array}$ & Recovery / \% \\
\hline $\mathrm{Al}$ & $32.3 \pm 0.1$ & $15.1 \pm 0.55$ & 47 \\
$\mathrm{As}$ & $0.016 \pm 0.001$ & $0.015 \pm 0.002$ & 94 \\
$\mathrm{Ba}$ & $0.46 \pm 0.02$ & $0.44 \pm 0.01$ & 96 \\
$\mathrm{Co}$ & $0.11 \pm 0.01$ & $0.11 \pm 0.01$ & 100 \\
$\mathrm{Cr}$ & $0.21 \pm 0.01$ & $\mathrm{ND}$ & - \\
$\mathrm{Cu}$ & $38.9 \pm 1.8$ & $38.1 \pm 1.3$ & 98 \\
$\mathrm{Mn}$ & $92.8 \pm 2.6$ & $91.9 \pm 2.5$ & 99 \\
$\mathrm{Mo}$ & $0.78 \pm 0.03$ & $0.76 \pm 0.01$ & 98 \\
$\mathrm{Ni}$ & $0.86 \pm 0.03$ & $0.85 \pm 0.06$ & 99 \\
$\mathrm{~Pb}$ & $0.051 \pm 0.001$ & $0.048 \pm 0.002$ & 95 \\
$\mathrm{Se}$ & $1.58 \pm 0.02$ & $1.61 \pm 0.07$ & 102 \\
$\mathrm{Sr}$ & $2.60 \pm 0.15$ & $2.54 \pm 0.12$ & 98 \\
$\mathrm{~V}$ & $0.14 \pm 0.01$ & $0.13 \pm 0.01$ & 96 \\
$\mathrm{Zn}$ & $56.4 \pm 1.8$ & $57.5 \pm 2.5$ & 102 \\
\hline $\mathrm{MW}$ &
\end{tabular}

MW:microwave; ND: no interference-free isotope available for quantitation. species has its own capacity to uptake and accumulate various elements, ${ }^{1,22}$ despite their being harvested from the same geographic region of Brazil, i.e., from a soil rich in Se and Ba. In contrast to the Brazil nuts, concentrations of Se and Ba present in babassu coconut are much lower, 0.54 and $0.20 \mathrm{mg} \mathrm{kg}^{-1}$, respectively.

Babassu coconut presents concentrations of $\mathrm{Al}$ and $\mathrm{Zn}$ comparable to those reported by Naozuka et al. ${ }^{13}$

\section{Oil fractions}

Formic acid extraction of the elements from the oil fractions derived from the samples was not efficient. However, microwave-assisted digestions of this fraction allowed quantitation of the trace elements by ICP-MS.

Table 7 summarizes the trace element content in the oil fraction derived from both materials. Taking into account the mass fraction of oil comprising the samples (64 and $66 \%$ for Brazil nut and babassu coconut, respectively), it can be inferred that $50 \% \mathrm{Al}, 86 \% \mathrm{Cr}, 30 \% \mathrm{Ni}$ and $8 \%$ of $\mathrm{Sr}$ content is present in the Brazil nut oil fraction. These trends compliment results reported by Welna et al., ${ }^{12}$ who utilized various reagents (solvents) for extraction of the lipid fraction of Brazil nuts, finding $\mathrm{Cr}(85-100 \%)$ and $\mathrm{Ni}$ $(50-70 \%)$ in the oil fraction.

Table 7. Results for microwave-assisted digested oil samples $(n=3)$

\begin{tabular}{lcc}
\hline Element & $\begin{array}{c}\text { Brazil nut oil/ } \\
\left(\mathrm{mg} \mathrm{kg}^{-1}\right)\end{array}$ & $\begin{array}{c}\text { Babassu coconut oil/ } \\
\left(\mathrm{mg} \mathrm{kg}^{-1}\right)\end{array}$ \\
\hline $\mathrm{Al}$ & $1.81 \pm 0.10$ & $1.96 \pm 0.10$ \\
$\mathrm{As}$ & $<0.0062^{\mathrm{a}}$ & $<0.0062$ \\
$\mathrm{Ba}$ & $<0.032$ & $0.07 \pm 0.01$ \\
$\mathrm{Co}$ & $<0.0026$ & $<0.0026$ \\
$\mathrm{Cr}$ & $0.26 \pm 0.01$ & $0.17 \pm 0.01$ \\
$\mathrm{Cu}$ & $<0.064$ & $<0.064$ \\
$\mathrm{Mn}$ & $<0.029$ & $<0.029$ \\
$\mathrm{Mo}$ & $<0.012$ & $<0.012$ \\
$\mathrm{Ni}$ & $0.99 \pm 0.06$ & $0.05 \pm 0.01$ \\
$\mathrm{~Pb}$ & $<0.0052$ & $<0.0052$ \\
$\mathrm{Se}$ & $<0.076$ & $<0.076$ \\
$\mathrm{Sr}$ & $17.8 \pm 0.9$ & $0.34 \pm 0.02$ \\
$\mathrm{~V}$ & $<0.0076$ & $<0.0076$ \\
$\mathrm{Zn}$ & $<0.110$ & $<0.110$ \\
\hline
\end{tabular}

Limit of quantification.

For babassu coconut, the oil fraction contained 10, 20, 60,10 and $20 \%$ of the total element content of $\mathrm{Al}, \mathrm{Ba}, \mathrm{Cr}$, $\mathrm{Ni}$ and $\mathrm{Sr}$, respectively, in this sample. Although babassu oil is widely used in the manufacture of cosmetics and is used in foods, there are unfortunately no published studies 
concerning the composition of trace elements in this nut sample.

\section{Conclusions}

As solutions obtained following the described ultrasound and heating steps using formic acid required filtering prior to analysis, it is clear that this process is equivalent to an "extraction", rather than a complete solubilization or digestion. Filtration precluded any problems with particles clogging the nebulizer; obviously, this does not impact the analysis of such preparations when determinations are performed by GF AAS, in which case the process may be considered to be a solubilization. Nevertheless, a formic acid extraction approach provides a greener, simpler and less expensive alternative to acid digestions for sample preparation for the subsequent determination of trace elements in such samples. Moreover, the resultant digests may be suitable for direct use of photochemical vapor generation for a number of these elements ${ }^{25}$ to enhance sample introduction efficiency and improve LOQs.

Optimization of the extraction procedure using chemometric tools allows mapping the entire experimental domain studied. Thus it may be inferred that some elements ( $\mathrm{Mn}, \mathrm{Ni}, \mathrm{Pb}, \mathrm{Sr}$ and $\mathrm{V}$ ) are readily extracted following the simplified procedure as described in the literature. However, the extraction of $\mathrm{Ba}, \mathrm{Co}$ and Mo require $3 \mathrm{~h}$ in an ultrasonic bath $\left(50^{\circ} \mathrm{C}\right)$ and only for quantitative extraction of As, $\mathrm{Cu}, \mathrm{Se}$ and $\mathrm{Zn}$ is it necessary to include a heating step in a thermostated bath for $7 \mathrm{~h}$.

Treatment of the oil fractions with formic acid in an attempt to extract them was unsuccessful. More studies are needed to thoroughly investigate this approach. The relatively high fractions of elements such as $\mathrm{Cr}$ and $\mathrm{Ni}$ remaining in the lipid phase may be of interest from the perspective of speciation of these elements. To date, only speciation of Se has been studied. ${ }^{15,26}$

\section{Acknowledgments}

The authors are grateful to Coordenação de Aperfeiçoamento de Pessoal de Nível Superior (CAPES, Brazil) for financial support to G. S. L. (BEX 9263/13-6).

\section{References}

1. Todoli, J. S. In Liquid Sample Introduction in ICP Spectrometry - A Practical Guide; Todoli, J. S.; Mermet, J. M., eds.; Elsevier: New York, 2008, pp. 147-190.

2. Nóbrega, J. A.; Santos, M. C.; Sousa, R. A.; Cadore, S.; Barnes, R. M.; Tatro, M.; Spectrochim. Acta, Part B 2006, 61, 465.
3. Scriver, C.; Kan, M.; Willie, S.; Soo, C.; Birnboim, H.; Anal. Bioanal. Chem. 2005, 381, 1460.

4. Schrijver, I.; Aramendia, M.; Resano, M.; Dumoulin, A.; Vanhaecke, F.; J. Anal. At. Spectrom. 2008, 23, 500.

5. Tormen, L.; Gil, R. A.; Frescura, V. L. A.; Martinez, L. D.; Curtius, A. J.; Spectrochim. Acta, Part B 2010, 65, 959.

6. Narukawa, T.; Willie, S.; J. Anal. At. Spectrom. 2010, 25, 1145.

7. Vieira, M. A.; Ribeiro, A. S.; Curtius, A. J.; Sturgeon, R. E.; Anal. Bioanal. Chem. 2007, 388, 837.

8. Nobrega, J. A.; Sturgeon, R. E.; Grinberg, P.; Gardner, G. J.; Brophy, C. S.; Garcia, E. E.; J. Anal. At. Spectrom. 2011, 26, 2519.

9. Sturgeon, R. E.; Grinberg, P.; J. Anal. At. Spectrom. 2012, 27 , 222.

10. Suzuki, T.; Sturgeon, R. E.; Zheng, C.; Hioki, A.; Nakazato, T.; Tao, H.; Anal. Sci. 2012, 28, 807.

11. Grinberg, P.; Sturgeon, R. E.; Gardner, G. J.; Microchem. J. 2012, 105, 44.

12. Welna, M.; Klimpel, M.; Zyrnicki, W.; Food Chem. 2008, 111, 1012.

13. Naozuka, J.; Vieira, E. C.; Nascimento, A. N.; Oliveira, P. V.; Food Chem. 2011, 124, 1667.

14. Santos, O. V.; Correa, N. C. F.; Carvalho Jr., R. N.; Costa, C. E. F.; França, L. F. F.; Lannes, S. C. S.; Food Res. Int. 2013, 51,841 .

15. Dumont, E.; Pauw, L.; Vanhaecke, F.; Cornelis, R.; Food Chem. 2006, 95, 684.

16. Brown, K. M.; Arthur, J. R.; Public Health Nutr. 2001, 4(2B), 593.

17. Wurfels, M.; Jackwerth, E.; Stoeppler, M.; Anal. Chim. Acta 1989, 226, 1 .

18. Wurfels, M.; Jackwerth, E.; Stoeppler, M.; Anal. Chim. Acta 1989, 226, 17.

19. Deringer, G.; Suich, R.; J. Qual. Technol. 1980, 12, 214.

20. Rodushkin, I.; Nordlund, P.; Engstrom, E.; Baxter, D.; J. Anal. At. Spectrom. 2005, 20, 1250.

21. Todoli, J. S.; Mermet, J. M.; Canals, A.; Hernandis, V.; J. Anal. At. Spectrom. 1998, 13, 55.

22. Pettine, M.; Casentini, B.; Mastroianni, D.; Capri, S.; Anal. Chim. Acta 2007, 599, 191.

23. Chang, J. C.; Gutenmann, W. H.; Reid, C. M.; Lisk, D. J.; Chemosphere 1995, 30, 801.

24. Parekh, P. P.; Khan, A. R.; Torres, M. A.; Kitto, M. E.; J. Food Compos. Anal. 2008, 21, 332.

25. Wu, P.; He, L.; Hou, X.; Zheng, C.; Sturgeon, R. E.; J. Anal. At. Spectrom. 2010, 25, 1217.

26. Jayasinghe, S. B.; Caruso, J. A.; Int. J. Mass Spectrom. 2011, $307,16$.

Submitted: September 6, 2015

Published online: January 26, 2016 